ISSN 2656-839X

\title{
PERANAN MAJELIS DZIKIR DALAM PEMBENTUKKAN KARAKTER REMAJA
}

\author{
Maturidi matur679@gmail.com \\ Masruroh yesiimas57@gmail.com \\ Program Studi Pendidikan Agama Islam IAIN La Raiba Bogor
}

\section{ABSTRACT}

This study aims to find out how the role of the Dhikr Council in the formation of adolescent characters carried out in the Assembly of Dhuafa Tapos Tenjolaya Bogor, Morals or character is human behavior in daily life that has been attached to a person. Morals relating to matters relating to good deeds, bad, right and wrong in the actions of a human being whose role model is sourced from the Qur'an and the hadith of the Messenger of Allah. In this case, the Dhuafa Assembly as a dzikir council located in Tapos Tenjolaya Bogor has an important role and contribution in the formation of adolescent character. The writing method used in the study is a qualitative descriptive method. In this paper the author discusses the role of the Dhuafa Assembly in the formation of adolescent characters. As for the results of his research are: 1 . The Assembly's aim is to improve the heart (islah al-Qalbi) when his heart is good, his deeds will be good 2. The Council of the poor as pioneers in every activity, 3. The Dhuafa Assembly not only conducts dhikr, prayer but also organizes activities to shape the character of adolescents 4 . There are factors driving and inhibiting the activities of forming the character of adolescents

Keyword: Character, Dhikr Council, Dhuafa Council

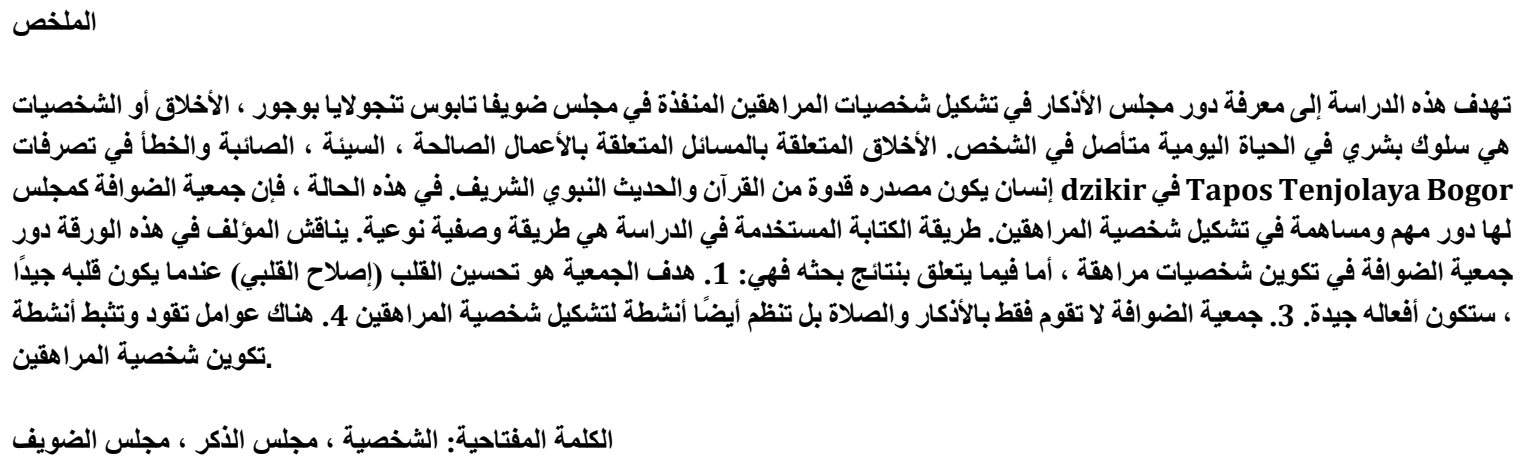

\section{ABSTRAK}

Penelitian ini bertujuan mencari tentang bagaimana peranan Majelis Dzikir dalam pembentukkan karakter remaja yang dilakukan di Majelis Dhuafa Tapos Tenjolaya Bogor, Akhlak ataupun karakter merupakan perilakumanusia dalam kehidupan sehari-hari yang telah melekat pada diri seseorang. Akhlakmenyangkut hal yang berhubungan dengan perbuatan baik, buruk, benar dan salahdalam tindakan seseorang manusia yang panutannya bersumber dari Al-Qur'an dan hadis Rasulullah SAW. Dalam hal ini Majelis Dhuafa sebagai majelis dzikir yang berada di Tapos Tenjolaya Bogor mempunyai peranan penting dan kontribusi dalam pembentukkan karakter remaja. Metode penulisan yang digunakan dalam penelitian tersebut dengan metode Deskriptif Kualitatif. Dalam tulisan ini penulis membahas tentang peranan Majelis Dhuafa dalam pembentukkan karakter remaja adapun hasil penelitiannya adalah: 1. Majelis secara tujuannya adalah memperbaiki hati(islah al-Qalbi) 
ketika hatinya baik maka amal perbuatannya akan baik 2. Majelis dhuafa sebagai pioner dalam setiap kegiatan, 3. Majelis Dhuafa tidak hanya mengadakan dzikir, shalawatan namun mengadakan kegiatan-kegiatan untuk membentuk karakter remaja 4. Adanya faktor pendorong dan penghambat kegiatan pembentukkan karakter remaja

Keyword: Karakter, Majelis Dzikir, Majelis Dhuafa

\section{A. PENDAHULUAN}

Kehidupan muda mudi dewasa ini cenderung memprihatinkan, fenomena tersebut terjadi karena para kaula muda terlalu mengikuti hawa nafsu mereka, sehingga banyak yang lupa atas eksistensi dirinya serta esensi kemahakuasaan Tuhan. Hal ini turut berdampak pada kondisi kejiwaan yang membuat kehidupan tidak tabil, dan nilai akan berpengaruh pada ketaatan kepada Allah SWT (Ilyas, alwahidi dkk, Islam Tinjauan Spiritual dan Sosial h 91)

Kondisi kejiwaan dapat menimpa siapa saja, sekalipun orang kaya, atau orang yang berpendidikan tinggi dan para alim ulama. Semua akan mengalami kegetiran hidup, atau ketakutan yang berujung pada tekanan psikologis. Semakin jauh seseorang dari Allah SWT. Maka rasa gundah gulana akan semakin menggerogoti, terlebih lagi bagi generasi muda yang sedang merangkai masa depan yang penuh dengan tanda tanya. Apalagi muda mudi masih terlalu senang dengan gaya menyimpang serta mencoba hal-hal yang baru, dalam keadaan seperti ini bantuan keluarga berperan penting dalam mengarahkan anak-anaknya agar dapat melangkahkan kakinya pada jalan kebenaran bukan jalan keburukan. Selain pihak orang tua, masyarakat juga perlu memberikan perhatian khusus pada generasi muda agar tidak mudah jatuh pada hal yang negatif, untuk itu upaya semua pihak kea rah kebaikan sangat dibutuhkan.

Kemajuan material sebagai hasil dari teknologi yang telah menciptakan berbagai kemudahan bagi manusia dalam menjalani hidupnya. Hal ini banyak dilihat dari kebutuhan hidup, namun dalam kenyataannya kemajuan itu bukanlah garis lurus untuk kemudahan, kesenangan dan juga kenikmatan lahiriah yang dihasilkan oleh sains dan teknologi. Kemajuan-kemajuan tersebut tidak selalu memberikan kesenagan dan kepuasan batin semata, bahkan ada yang menganggap sebagai malapetaka bagi manusia, untuk mendapatkan kesenangan batin, banyak yang memilih taSAWuf sebagai terapi bagi derita yang dirasakannya ( Muhammad Arifin, dkk. Indonesia Berzikir risalah Anak Bangsa untuk Negeri Tercinta h 79).

Munculnya majelis majelis zikir di Indonesia tentu sangat menarik untuk dicermati, di tengah pola hidup yang semakin konsumeristik dan jauh dari nilai-nilai agama yang dipengaruhi oleh nilainilai materialistis, justru di pihak lain suasana religious spiritual juga semakin berkembang. Kegelisahan hidup ternyata makin parah meskipun disisi lain, perkembangan teknologi telah memanjakan umat manusia dengan segala temuannya. Begitu juga dengan banyak tugas yang membutuhkan tenaga besar digantikan oleh mesin-mesin yang serba elektronika. Meskipun fasilitas hidup telah didapat dengan mudah, tingkat stress manusia menghadapi hidup juga semakin tinggi, dengan demikian manusia telah kehilangan hakikat hidup yang sebenarnya.

Untuk mengobati kegelisahan spiritual dalam satu dekade ini beberapa lembaga zikir di Indonesia lahir, kehadiran majelis ini telah mendapat perhatian lebih dari masyarakat, dengan jumlah jamaah yang banyak ataupun sedikit. Namun efek kemunculan tersebut memberikan kontribusi atas kegundahan dan kegusaran spiritual sosial, baik remaja ataupun dewasa.

Majelis dzikir yang berada di Tapos tenjolaya yaitu Majelis Dhuafa seolah lahir untuk memberikan pencerahan kepada masyarakat sekitar yang dimana diprakarsai oleh orang-orang yang 
berlumur dosa, yang menyadari kebodohan dirinya serta yang tidak mampu untuk melaksanakan perintah Allah, lambat laun majelis ini berdiri untuk kegiatan zikir dan shalawatan mampu memberikan kontribusi kepada masyarakat khususnya remaja dalam membina akhlak remaja yang islami, dengan jiwa berzikir dan berfikir berjuang, berhasil bersyukur

\section{B. TINJAUAN LITERATUR DAN STUDI TERDAHULU}

\section{Pengertian akhlak}

Dalam Kamus Besar Bahasa Indonesia, kata akhlak diartikan dengan budi pekerti. Akhlak juga diartikannya sebagai ajaran tentang baik buruk yang diterima umum mengenai perbuatan, sikap, kewajiban, dsb. Akhlak juga diartikannya dengan kondisi mental yang membuat orang tetap berani, bersemangat, bergairah, berdisiplin, dan sebagainya, sebagaimana ia juga dipahami dalam arti isi hati atau keadaan perasaan, sebagaimana terungkap dalam perbuatan(M. Quraish Shihab, Yang Hilang dari Kita Akhlak. 2017)

Khuluq berarti suatu perangai (watak, tabiat) yang menetap kuat dalam jiwa sesorang dan merupakan sumber timbulnya perbuatan-perbuatan tertentu dari dirinya, secara mudah dan ringan, tanpa perlu dipikirkan dan direncanakan sebelumya. Maka, apabila dari perangai tersebut timbul perbuatan-perbuatan yang baik dan yang terpuji menurut akal sehat dan syariat, dapatlah ia disebut sebagai perangai atau khuluq yang baik. Sebaliknya, apabila yang timbul darinya adalah perbuatanperbuatan yang buruk, ia disebut sebagai khuluq yang buruk pula (Muhammad Al-Baqir, Mengobati Penyakit Hati Membentuk Akhlak Mulia. 28-29)

Pembagian akhlak

Berdasarkan sifatnya:

a) Akhlaqul mahmudah atau akhlaqul karimah

b) Akhlakul madzmumah atau akhlaqul sayyi'ah Sedangkan pembagian akhlak berdasarkan obyeknya

a) Akhlak kepada khalik (Tuhan)

b) Akhlak kepada makhluk, yang terbagi menjadi 5 yaitu:

1) Akhlak terhadap Rasulullah

2) Akhlak terhadap keluarga

3) Akhlak terhadap diri sendiri

4) Akhlak terhadap sesama

5) Akhlak terhadap alam lingkungan

Cara Menumbuhkan Akhlaq yang Baik

a) Melalui anugerah Ilahi dan kesempurnaan fitri

b) Dengan memperoleh perangai-perangai ini melalui perjuangan melawan nafsu (mujahadah) dan latihan-latihan ruhani (riyadhah).

Pengertian Majelis Dzikir

Majelis (مجلس) adalah kata tempat dari fi'il (kata kerja) : Jalasa(جلس) yang berarti duduk. Sehingga makna majelis ialah tempat duduk. Makna lain dari kata ini adalah segolongan orang yang diberi kekhususan melakukan pertimbangan terhadap berbagai amal yang diserahkan kepada meraka.( AlMu'jamul-Wasith hal 130), Makna yang lebih sederhana lagi adalah tempat duduk, tempat berkumpul untuk orang tertentu atau umum.

Kata dzikir, berasal dari bahasa Arab: ذكر - يذكر - ذكرا Iyang berarti:mengingat sesuatu di dalam hati atau menyebutnya dengan lidah.( Luwais Ma'luf, al-munjid fi al-Lughah wa al-'alam(Beirut Daar alMasyriq, 1986 hal 236), Menurut Abdullah 'Abbas al-Nadwi, kata dzikir (الذكر) mempunyai arti sebutan (mention), ingatan (remembrance/recollection) peringatan (reminder admonition) doa(invocation), nama baik (reputation) dan kemasyhuran (renown) 
Meskipun dalam pengertian diatas, dzikir diartikan "menyebut", namun perlu dijelaskan bahwa, substansi dari pada dzikir adalah meyebut, mengingat, memahami dan menyadari sifat-sifat terpuji Allah, melaui konsep tasbih, tahlil, tahmid, hauqalah, hasbalah, dan membaca doa-doa yang ma'tsur. Tetapi yang dimaksud dzikir di sini bukan dalam pengertian hafalan atau hanya amalan oral lisan yang dilakukan secara berulang-ulang dan dialunkan dengan irama tertentu saja, seperti apa yang dipahami sebagian muslim), akan tetapi amalan lisan dan hati yang dilakukan dengan penuh pengertian, pemahaman dan penyadaran

Jadi majelis dzikir yang dimaksud disini adalah tempat/kumpulan orang banyak yang mempunyai maksud dan tujuan tertentu hanya untuk mengingat Allah, mensucikan hati serta mendekatkan diri kepada Allah SWT

\section{METODE PENELITIAN}

a. Teknik pengumpulan data

Teknik pengumpulan data yang digunakan peneliti dalam penelitian ini adalah sebagai berikut :

1. Observasi

Peneliti mengamati secara langsung kegiatan yang sedang berlangsung. Pada kegiatan di majelis dzikir majelis dhuafa dengan memperhatikan secara akurat, mencatat segala fenomena yang muncul, dan mempertimbangkan hubungan antara aspek dengan fenomena tersebut. Adapun kegiatan yang di observasi yaitu kegiatan dzikir, kegiatan mingguan, serta peranan majelis dzikir. Dari pengamatan tersebut peneliti mendapatkan data tentang suatu masalah. Sehingga, diperoleh pemahaman atau pembuktian terhadap informasi.

2. Wawancara

Peneliti menjadi pewawancara yang akan mewawancarai informan atau narasumber. Adapun, yang diwawancarai pimpinan majelis dzikir yaitu Ustad Dede Badrutamam, peserta jamaah majelis dzikir dan santri yaitu Fauzi dan Ismail.

3. Dokumentasi

Peneliti mengambil suatu data dengan menggunakan dokumentasi berupa dokumen-dokumen baik tertulis maupun tidak tertulis, gambar, maupun elektronik dan blog majelis dzikir. Dokumen ini sebagai pelengkap dari penggunaan metode observasi dan wawancara dalam penelitian kualitatif.

b. Sumber Data

Dalam penelitian ini peneliti mencari data yang dibutuhkan untuk mencari data yang dibutuhkan adapun peneliti mengambil data antara lain:

1. Data Primer

Peneliti terjun ke lapangan mencari informasi dari informan dan narasumber yaitu individu atau perseorangan seperti hasil wawancara yang dihasilkan oleh peneliti. Data primer yang didapatkan antara lain catatan hasil wawancara atau transkrip wawancara, hasil-hasil observasi lapangan pengamatan. Informan atau narasumber dari Pimpinan Majelis dzikir, jamaah dan santri

2. Data Sekunder

Peneliti mencari data lain untuk mendukung data primer yaitu dengan mengambil gambar atau foto, dokumentasi, dan juga blog majelis dhuafa

c. Teknik Analisis Data

Peneliti dalam hal ini mengatur dalam mendapatkan data dengan mengurutkan data, mengorganisasikannya ke dalam suatu pola, kategori dan satuan uraian dasar. Dengan demikian, datadata lebih mudah dibaca dan disimpulkan. Teknik yang digunakan oleh peneliti yaitu teknik analisis 
data deskriptif. Dimana peneliti menghimpun data-data faktual dan mendeskripsikannya. Data tersebut berasal dari seluruh informasi yang diperoleh dari hasil wawancara, observasi, serta dokumen-dokumen melalui beberapa tahap. Setelah pengumpulan data, pencatatan data peneliti melakukan analisis interaksi yang terdiri dari reduksi data, penyajian data dan verifikasi. Analisis dari penelitian ini berlangsung bersamaan dengan proses pengumpulan data ataupun dilakukan setelah data-data terkumpul.

1. Pengumpulan data

Peneliti menggali informasi dan data dari berbagai sumber yaitu dengan wawancara, observasi, analisis dokumen dan foto-foto kegiatan yang ada di majelis dzikir.

2. Reduksi data

Di dalam mereduksi data peneliti memperoleh data menyeleksi atau menyortir data dari hasil wawancara merupakan data yang memiliki sifat yang sangat luas bahkan masih mentah, peneliti bisa memilih laporan hasil wawancara yang penting dan apabila merasa ada data yang dirasa kurang penting tidak dimasukan ke dalam laporan. Adapun langkah-langkah reduksi data melibatkan beberapa tahapan. Tahap pertama, melakukan editing, pengelompokan, dan meringkas data. Tahap kedua, menyusun kode-kode dan catatan-catatan mengenai berbagai hal yang berkaitan dengan data yang sedang diteliti sehingga peneliti dapat menentukan tema-tema, kelompok-kelompok, dan pola-pola data. Pada tahap terakhir dari reduksi data yaitu menyusun rancangan konsep-konsep serta penjelasan-penjelasan berkenaan dengan tema, pola, atau kelompok yang bersangkutan.

3. Penyajian data

Hasil dari pengorganisasian data yang disajikan secara sistematis dapat dibentuk dalam sebuah laporan. Untuk penyajian laporan, berupa deskriptif analitik dan logis yang mengarah pada kesimpulan. Dalam tahap ini peneliti dituntut untuk melakukan penafsiran terhadap data dalam wawancara/transkrip wawancara.

4. Penarikan kesimpulan/verifikasi

Penarikan kesimpulan menyangkut interpretasi yaitu pengembangan makna dari data yang ditampilkan. Kesimpulan yang masih kaku senantiasa di verifikasi selama penelitian berlangsung, sehingga diperoleh kesimpulan yang kredibelitas, objektivitasnya terjamin dan dapat dipertanggungjawabkan. Verifkasi dapat berupa pemikiran kembali yang melintas dalam pikiran peneliti saat mengadakan pencatatan atau dapat berupa suatu tinjauan ulang terhadap catatancatatan

5. Teknik keabsahan data

a. Triangulasi

Peneliti membandingkan data yang diperoleh dalam wawancara dengan data observasi, kemudian membandingkan apa yang diktakan orang di depan umum dengan apa yang dikatakannya secara pribadi, membandingkan apa yang dikatakan orang-orang tentang situasi dengan apa yang dikatakan sepanjang waktu, membandingkan hasil wawancara dengan isi dokumen yang berkaitan. Penelitian ini menggunakan triangulasi teknik dilakukan dengan cara mengecek data kepada sumber yang sama dengan teknik yang berbeda.

b. Perpanjangan pengamatan

Peneliti memperpanjang pengamatan dalam penelitian ini yaitu peneliti kembali ke lapangan melakukan pengamatan, wawancara lagi dengan informan yang pernah ditemui maupun yang baru. Dengna perpanjangan pengamatan, hubungan peneliti dengan informan akan semakin terbentuk raport, semakin akrab (tidak ada jarak lagi) semakin terbuka, saling mempercayai sehingga tidak ada informasi yang disembunyikan lagi. Bila terbentuk raport, maka telah terjadi kewajaran dalam penelitian, dimana kehadiran peneliti tidak lagi mengganggu perilaku yang dipelajari. 


\section{c. Peningkatan ketekunan}

Meningkatkan ketekunan berarti melakukan pengamatan secara lebih cermat dan berkesinambungan. Dengan cara tersebut maka kepastian data dan urutan peristiwa akan dapat direkam secara pasti dan sistematis

\section{HASIL DAN PEMBAHASAN}

Profil dan sejarah berdiri majelis dhuafa

Berawal dari kegundahan hati dan keinginan untuk memperbaiki gaya hidup dari hal yang kurang bermanfaat ke arah yang lebih bermanfaat, maka majelis dhuafa berupaya membuat kegiatan dzikir jama'i dan 'mudzakaroh. Setelah berlangsung terpikirlah bahwa majelis dhuafa membutuhkan identitas, maka pendiri selaku orang yang dituakan dengan kesepakatan ikhwan memberi identitas perkumpulan ini dengan nama majelis dhuafa.

Kata majelis merupakan isim makan dari jalasa yang berarti duduk, maka majelis merupakan tempat duduk atau bisa juga menjadi isim zaman. Sedangkan dhuafa jamak dari dhaif yang berarti yang lemah. Maka majelis dhuafa merupakan tempat duduk dan berkumpulnya yang merasa dirinya llemah di hadapan Allah SWT. Lemah karena menyadari akan dosa-dosa, lemah karena merasa tiada secuil ketakutan yang dimiliki kecuali dari Allah SWT

Visi dan misi majelis dhuafa

Visi : Majelis dhuafa menyadari betapa manusia sulit merasa dan menyadari akan kelemahan dirinya, hal ini disebabkan ketidaktahuan atau kekhilafan akan kedudukannya di mata Allah serta lupa akan tujuan penciptaannya. Oleh karena itu untuk mengingatkan diri jamaah majelis dhuafa khususnya umat secara keseluruhan, maka kami membuat sepotong kalimat yang menjadi visi, dengan harapan jamaah majelis mengerti arah tujuan majelis yaitu untuk kembali pada kedudukan manusia di hadapan Allah dan tugasnya di alam semesta ini. Visi tersebut adalah : jadilah kamu seorang hamba sebelum menjadi khalifah

Dari visi tersebut menggambarkan bahwa tugas manusia secara umum terbagi menjadi 2, yaitu sebagai hamba Allah dan khalifah di muka bumi. Hamba Allah yang sesungguhnya adalah mereka yang tergolong orang-orang yang bertaqwa, setiap gerak langkahnya hanya tertuju dan untuk mencari ridho Allah. Karena orang yang berakhlaklah yang mengerti bahwa tujuan utama penciptaannya adalah untuk ibadah, mengabdi, menyembah kepada Allah.

Tujuan penciptaan manusia selanjutnya adalah sebagai khalifah di muka bumi, yang bertanggung jawab untuk mengurusi, menjaga dan melestarikan apa yang telah Allah ciptakan. Manusia sebagai khalifah merupakan wakil Allah di alam ini. Hal ini bukan berarti Allah terhijab dari sifat kuasa-Nya. Akan tetapi manusia dijadikan khalifah di muka bumi sebagai ujian baginya sejauh mana ketaatannya kepada Allah, karena di dunia ini merupakan perhiasan yang kerap kali menipu manusia. Maka apabila kehambaan seorang manusia belum sempurna atau belum menghambakan diri seutuhnya kepada Allah, maka kekhalifahannya di bumi ini akan rusak dan merusak. Oleh sebab itu, jadilah seorang hamba (taqwa) sebelum menjadi khalifah

$$
\text { كُنْ عَابِدًا قَبْلَ أَنْ تَكُوْنَ خَلِيْفَةً }
$$

Misi : dalam mewujudkan visi di atas maka majelis dhuafa membuat program melalui misi-misi yang menurut majelis dhuafa dapat mengantarkan mereka kepada kesadaran akan tujuan penciptaan manusia serta dapat menjadi hamba Allah dan khalifah yang diridhoi-Nya. Misi tersebut antara lain:

a. Membudayakan tadarus al-qur'an 
Al-qur'an merupakan petunjuk bagi umat islam yang beriman, baik bagi mereka yang memahami isi kandungannya maupun bagi mereka yang hanya mampu membacanya. Apa betul orang yang tidak memahami kandungan al qur'an dapat menjadi petunjuk? Jawabannya "iya". Itulah al-qur'an yang kita yakini kalamullah, wahyu suci dan mukjizat terbesar yang hanya Allah berikan kepada Rasulullah Muhammad SAW dan kita sebagai umatnya.

b. Mengadakan majelis ilmi

Maksud dari majelis ilmi adalah mengadakan kumpulan, duduk bersama untuk mengaji dan mengkaji pengetahuan khususnya tentang ilmu syariat baik fikih, tauhid taSAWuf dan lain-lain. Kegiatan ini dilaksanakan kapan saja majelis dhuafa berkumpul, karena kesibukan jamaah majelis yang berada jauh dari majelis. Akan tetapi majelis ilmi yang terprogram dalam agenda majelis dhuafa adalah sekali dalam sebulan. Hal ini majelis dhuafa adakan mengingat pentingnya ilmu sebagai landasan kita beribadah.

c. Mengadakan majelis dzikir

Majelis Dzikir adalah tempat duduk atau waktu saat jamaah duduk mengadakan dzikir kepada Allah. Hal ini sama dengan ketentuan majelis ilmi yang terprogram hanya sekali dalam satu bulan. Adapun dzikir yang dawamkan disetiap bulannya antara lain istighfar, sholawat, dan kalimat thoyyibah.

Istighfar merupakan dzikir yang memiliki makna permohonan pengampunan dosa, bukan sekedar ampunan Allah yang ingin kami capai, tetapi kesadaran akan dosa-dosa yang telah kita perbuat. Karena tanpa kesadaran itu mustahil Allah akan mengampuni dosa-dosa kita.

Sholawat tentunya tertuju kepada Nabi Muhammad SAW. Yang menurut ulama fiqh ketika kita bersholawat maka pahala tersebut sampai kepada Rasulullah, karena Rasulullah adalah manusia yang sempurna yang dilimpahi segala bentuk keberkahan dan keselamatan, maka pahala sholawat yang kita sampaikan akan kembali kepada kita. Akan tetapi majelis dhuafa tidak mengarahkan hal itu. Akan tetapi lebih kepada sanjungan, pujian, dan ungkapan terima kasih melalui sholawat tersebut karena jamaah dapat merasakan dan menjadi umat beliau, yang mudah-mudahan bukan hanya kita yang mengaku umat Nabi Muhammad tetapi Nabi Muhammad mengakui kita sebagai umatnya. Urusan pahala dan tek-tek bengeknya kita serahkan kepada dzat yang Maha Tahu Allah SWT.

Kalimat thoyyibah (لا إله إلا اله) yang berisi Nafyun dan Istbat merupakan kalimat tauhid yang akan melunturkann penyakit qolbu. Jangan bangga ketika kita rajin sholat berjamaah di masjid, jangan merasa dermawan ketika kita rajin bersodaqoh. Tapi coba tanya diri kita, masih adakah perasaan lain selain Allah saat kita beramal dan beribadah..? Jika masih ada, itulah yang akan merusak dan tertolaknya amal yang kita lakukan. Hal ini tersembunyi hanya individu masing-masing yang dapat merasakan penyakit seperti ini dan ini merupakan syirkul lughoh dan syirkul khofi. Kalimat toyyibah inilah obatnya dan Allah lah yang akan menyembuhkan penyakit tersebut, namun jika kita tidak mau obat tersebut maka penyakit itu akan semakin menjalar dan membunuh qolbu.

a. Menghidupkan sunnah Rasul

b. Sunnah banyak digunakan dalam cabang ilmu islam, dalam fiqh sunnah memiliki arti suatu amal jika dilaksanakan mendapat pahala bila ditinggalkan tidak berdosa. Dalam ilmu hadits memiliki arti segala perbuatan, perkataan, dan persetujuan Rasulullah SAW.

c. Membudayakan silaturahim

Silaturahmi atau di Indonesia lebih populer dengan sebutan silaturahim merupakan salah satu kebiasaan atau sunnah serta anjuran Rasulullah SAW. Bukan hanya Rasulullah, tetapi Allah di dalam Alqur'an pun menyinggung tentang silaturahim. Majelis dhuafa sangat menekankan kepada jama'ah untuk membudayakan silaturahim tanpa memandang level. Jika kita mau memperhatikan silaturahim yang terjadi di negeri ini bukan atas dasar lillah, tetapi memiliki tujuan lain. Seorang kepala desa datang kepada kepala camat dengan maksud tertentu, seorang camat, bupati, guberur datang kepada 
anggota dewan semata-mata untuk menyampaikan sesuatu yang terkadang bukan untuk kemaslahatan umat atau masyarakat, tetapi menjual umat dan masyarakat untuk keuntungan pribadi.

Begitu juga halnya dengan ikhwan yang menyandang gelar ustadz, kyai bahkan ulama. Janganlah pilih-pilih untuk bersilaturahim. Ikhwan yang berada di garis tengah janganlah ragu untuk silaturrahim kepada pejabat dan ulama. jika ada keraguan untuk berangkat bersilaturrahim kepada orang di atas atau di bawah kita, berarti kita belum tulus karena Allah.

Silaturrahim bertujuan mengungkap apa yang terhijab, mengetahui isu yang tidak jelas, sehingga hubungan antara rakyat dan pejabat, ulama dengan umat senantiasa saling mengisi dan saling mengingatkan karena siapapun dia ulamakan, pejabatkah apalagi kita yang hanya rakyat jelata, semua memiliki musuh yang sama yaitu syaithonirrojim yang tak pernah alpa untuk menggoda kita semua agar keluar dari jalan yang lurus, jalan yang Allah berikan kepada para anbiya wal mursalin, auliya washolihin

Tujuan dan fungsi majelis dhuafa

Menurut pimpinan Majelis Dhuafa tujuan didirikannya Majelis ini adalah agar manusia-manusia menyadari tugas pokoknya sebagai hamba Allah SWT dan juga khalifah di muka bumi serta untuk menumbuhkan kesadaran lewat Qolbu.

Tujuan dan fungsi dibangunnya majelis dhuafa adalah untuk membentuk kepribadian yang islami dan memperbaiki serta mensucikan hati para jamaah agar tercipta kebaikan pada setiap amal perbuatan mereka sebagaimana disebutkan pada hadits sebagai berikut:

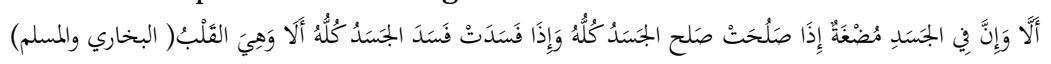

"Ketahuilah, sesungguhnya dalam tubuh manusia ada segumpal daging, jika segumpal daging itu baik, maka akan baik seluruh tubuh manusia dan jika segumpal daging itu buruk, maka akan buruk seluruh tubuh manusia, ketahuilah bahwa segumpal daging itu adalah hati manusia" (HR Bukhari dan Muslim).

Bentuk dan jenis dzikir yang diterapkan

Dari informasi yang didapat oleh peneliti bahwa bentuk dan jenis dzikir yang diterapkan antara lain:

a. Dzikir harian berasal dari TQN Suryalaya melalui Talqin KH. Zainal Abidin

b. Dzikir bulanan melalui istighfar, shalawat dan kalimat toyyibah sebelum dzikir biasanya dilaksanakan tausiah dari Pimpinan Majelis Dhuafa dan shalat taubat, shalat hajat, shalat tasbih dan ditutup dengan shalat witir

Latar Belakang Jamaah Majelis Dhuafa

Dilihat dari jumlah jamaah yang mengikuti majelis Dhuafa banyak dari jamaah yang latar belakangnya bermacam-macam diantaranya sebagai berikut:

a. Anak punk yang berada di jalanan khususnya di kec. Tenjolaya

b. Supir angkot

c. Pekerja dan buruh swasta

d. Mereka yang dipandang buruk oleh masyarakat

e. Buzer

Merupakan singkatan dari budak zero atau anak-anak yang sebelumnya merupakan sekumpulan anak yang nakal tetapi sekarang sudah insyaf dan ingin menjadi pribadi yang kebih baik lagi

Panca jiwa 
Seluruh kehidupan dan kegiatan di Majelis Dhuafa Tapos Tenjolaya didasarkan pada nilai-nilai yang dijiwai oleh suasana-suasana yang dapat disimpulkan dalam panca jiwa sebagai pedoman dan filosofi hidup bagi warga, jamaah, santri, majelis dhuafa. Adapun pancajiwa yang mendasari kehidupan di majelis dhuafa antara lain:
a. Berdzikir
b. Berfikir
c. Berjuang
d. Berhasil
e. Bersyukur

Motto

Sebagai pelengkap dan penyempurna dari panca jiwa Majelis Dhuafa Tapos Tenjolaya Bogor dan upaya menekankan kepada pembentukan pribadi mukmin, muslim yang kuat didasari dengan semboyan atau motto di bawah ini:
a. Keikhlasan
b. Kesadaran
c. Kebersamaan
d. Kekuatan

\section{Peranan Majelis Dhuafa dalam pembentukan karakter remaja}

Majelis Dhuafa dengan segala kekurangannya berusaha lebih baik dan memberikan yang terbaik kepada jamaah, upaya untuk memberikan lebih baik kepada jamaah dan santri diadakan kegiatankegiatan sebagai saran untuk membentuk karakter remaja dalam hal ini Majelis sebagai pioner yaitu pelopor dalam kegiatan yang mengajak, mengawali, merangkul untuk kebersamaan

Adapun kegiatan-kegiatan tersebut dituangakan dalam pemaparan berikut ini, antara lain: Kegiatan Majelis Dzikir

Kegiatan yang ada di Majelis Dhuafa sangat banyak yang dilaksanakan untuk mendukung karakter remaja, namun dalam upaya untuk melaksanakan visi dan misi kegiatan di majelis Dhuafa dibagi kedalam:

Kegiatan utama

\section{1) Membudayakan tadarus al-qur'an}

Al-qur'an merupakan petunjuk bagi umat islam yang beriman baik bagi mereka yang memahami isi kandungannya maupun bagi mereka yang hanya mampu membacanya. Apa betul orang yang tidak memahami kandungan al-qur'an dapat menjadi petunjuk? Jawabannya "ya". Itulah al-qur'an yang kita yakini kalamullah, wahyu suci dan mukjizat terbesar yang hanya Allah berikan kepada Rasulullah SAW dan kita sebagai umatnya.

Banyak ilmuwan-ilmuwan barat yang sudah meneliti betapa al-qur'an mampu memberi energi positif kepada manusia, baik ia mengerti kandungannya atau hanya mampu membaca bahkan bagi mereka yang hanya mendengar tanpa memiliki kemampuan membaca sekalipun. Akan tetapi bukan berarti kita hanya diam di posisi mendengar ataupun membaca saja, tetapi kita harus senantiasa mempelajari bacaan, kandungan serta syarat-syarat yang tidak mampu terungkap oleh mata dan otak kita. Semua itu diperlukan kedekatan kita kepada al-qur'an. Rasulullah SAW bersabda "Barangsiapa membaca al-qur'an, mempelajari kadungannya, dan menghalalkan yang al-qur'an halalkan serta mengharamkan apa yang al-qur'an haramkan (mengamalkan) maka akan dimasukan dalam syurga".

2) Mengadakan majelis ilmi 
Maksud dari majelis ilmi adalah mengadakan kumpulan, duduk bersama untuk mengaji dan mengkaji pengetahuan khususnya tentang ilmu syariat baik fikih, tauhid, taSAWuf, dan lain-lain. Kegiatan ini dilaksanakan kapan saja saat majelis dhuafa berkumpul, karena kesibukan jamaah majelis yang berada jauh dari majelis. Akan tetapi majelis ilmi yang terprogram dalam agenda majelis dhuafa adalah sekali dalam sebulan. Hal ini kami adakan mengingat pentingnya ilmu sebagai landasan kita beribadah.

Kegiatan pendukung

1) Yasling (Yasinan Keliling)

Adalah kegiatan yang dilakukan oleh jamaah dan santri ketika ada yang meninggal, syukuran, selametan 4 bulanan dari lingkungan masyarakat sekitar. Jamaah dan santri datang ke tempat tersebut tanpa meminta balasan ataupun upah. Ada juga yang diundang secara khusus ke tempat sohibul hajat.

2) Muhadhoroh (Latihan Pidato)

Merupakan latihan yang dilakukan santri pondok al-munawar dan beberapa jamaah majelis dhuafa. Latihan ini dilakukan pada 2 minggu sekali di setiap awal bulan dalam rangka mengasah kemampuan berbicara di depan umum dan melatih kepercayaan diri.

3) I'tikaf 10 akhir di bulan Ramadhan

Kegiatan ini dilakukan di masjid darussalam, pondok al-munawar, dan di masjid aldepos. Dilakukan untuk mengasah kesabaran anak, meningkatkan keimanan, dan mendekatkan diri kepada Allah.

4) Tarawih keliling

Untuk merealisasikan visi dan misi dari majelis dhuafa diadakanlah kegiatan tarawih keliling ke seluruh musholla di lingkungan majelis dhuafa atau di desa Tapos 2. Adapun musholla yang dikunjungi yaitu Mushalla Nurul iman, masjid Darussalam, Mushalla Mamba'us sa'adah, al-barokah, baitus solihin, dan lain-lain kegiatan ini untuk mempererat tali ukhuwah islamiyah di kalangan remaja

5) Takbir keliling di lingkungan Desa Tapos 2 ke seluruh Mushallah

Untuk meramaikan takbir di setiap musholla di lingkungan majelis dhuafa, Jaisy dhuafa (pasukan majelis dhuafa) bersilaturahim ke musholla-musholla serta melakukan takbir dan tahmid bersama di tempat tersebut

6) Iftor jama'i (buka bersama)

Salah satu kegiatan yang dilakukan oleh pemuda-pemudi dan mengundang aparatur negara dalam rangka buka bersama untuk mempererat tali silaturahim. Dan pada tahun ini dilakukan pada tanggal 9 juni 2018 bekerja sama dengan MA Sahid

7) Santunan anak yatim

Santunan anak yatim dilakukan oleh jamaah dan santri Pondok Al-Munawar setahun dua kaliyaitu pada tanggal 25 Ramadhan bertepatan dengan buka bersama dan ketika acara milad Majelis Dhufa dalam rangka membantu anak-anak yatim, mengharapkan pahala serta ridho dari Allah SWT.

8) Milad majelis dhuafa dan pentas seni

Untuk menumbuhkan rasa memiliki dan tanggung jawab terhadap majelis dhuafa dan ajang silaturahim di kalangan para jamaah diadakan milad dan pentas seni tahunan pada tanggal 14 april di setiap tahunnya. Adapun peserta dalam pentas seni yaitu dari Pondok Al-Munawar, TPA, dan BTQ dengan berbagai macam karya seni seperti marawis, puisi, drama, sholawatan, dan lain-lain.

9) Merayakan Maulid Nabi Muhammad SAW 
Maulid nabi dirayakan di majelis dhuafa pada setiap 12 rabiul awal dalam rangka melestarikan dan mengenang sebagai suri tauladan yang agung panutan manusia yaitu baginda Nabi Muhammad SAW serta meningkatkan kecintaan para jamaah terhadap Rasulullah.

1. Membuat iklim dan suasana yang baik di lingkungan Majelis Dhuafa

Majelis dhuafa berusaha menciptakan iklim serta suasana yang baik agar dapat memberikan kontribusi di masyarakat dalam rangka pembentukkan karakter. Kegiatan tersebut antara lain yaitu:

a. Selalu melaksanakan shalat 5 waktu secara berjama'ah

Para jama'ah selalu melaksanakan shalat 5 waktu secara berjama'ah dalam rangka menumbuhkan rasa semangat dalam beribadah dan menumbuhkan rasa kebersamaan.

b. Tidak menggunakan bahasa kasar dalam kegiatan sehari-hari

Dalam pembentukkan karakter tentu ditanamkan kebiasaan berbahasa yang sopan dan baik.

Tidak diperkenankan untuk menggunakan bahasa kasar dalam berkomunikasi.

c. Makan bersama dengan adab yang baik dan benar

Makan bersama diadakan untuk menciptakan rasa kebersamaan dan kekeluargaan namun tetap dengan adab yang baik dan benar sesuai ajaran islam.

d. Membiasakan salam, sapa, dan senyum

Untuk menjaga hubungan tetap baik maka diberlakukan kebiasaan untuk salam, sapa, dan senyum.

e. Membiasakan silaturahim

Agar terjaga ukhuwah islamiyah di antara para jama'ah maupun lingkungan sekitar maka dari itu dibiasakan kegiatan silaturahim.

f. Ikut serta dalam kegiatan sosial

Majelis dhuafa senantiasa mengikuti kegiatan sosial sebagai bentuk kepedulian terhadap masyarakat sekitar diantaranya mengikuti shalat jenazah, ataupun membantu mengurus jenazah

g. Membersihkan makam dengan bantuan IRMADA (Ikatan Remaja Masjid Darussalam)

Setiap 6 bulan sekali para jamaah maupun santri melakukan kegiatan sosial yaitu membersihkan makam umum yang berlokasi dekat Masjid Jami Darussalam dengan dibantu oleh IRMADA.

h. Minggu bersih

Setiap hari minggu dilaksanakan kerja bakti di Pondok Al-Munawar agar tercipta suasana yang nyaman dan sehat sebagai bentuk dari pengamalan syair arab yang berbunyi annazhaafatu minal iman

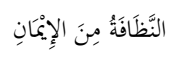

"Kebersihan sebagian dari iman."

i. Pengajian Pemuda Irmada( Ikatan Remaja Masjid Darussalam)

Upaya majelis dzikir untuk menambah wawasan dan pengetahuan yang lebih luas, para jamaah majelis dianjurkan mengikuti pengajian rutinan yang diadakan oleh Ikatan Remaja Masjid Darussalam pada hari Ahad Malam senin, adapun peserta pengajian dari kalangan remaja sebagian juga jamaah majelis Dhuafa. Jamaah pengajian tidak hanya dari desa Tapos 2 saja, namun berdatangan juga dari IRMA-IRMA( Ikatan Remaja Masjid) se Kecamatan Tenjolaya Bogor guna menguatkan tali silaturahim diantara pemuda-pemuda

j. Lari pagi 
Lari pagi dilaksanakan pada hari minggu pagi bertujuan untuk menjaga kesehatan tubuh dan melatih kekuatan fisik para jama'ah khususnya santri Pondok Al-Munawar sebagaimana disebutkan dalam syair arab yaitu al'aqlussalimi fil jismi salimu.

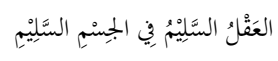

"Akal yang sehat terdapat dalam tubuh yang sehat"

\section{Faktor pendukung dan penghambat dalam pembentukkan karakter remaja}

Adapun faktor pendukung dalam kegiatan pembentukkan karakter remaja antara lain:

1. Iklim yang mendukung proses pembentukkan karakter remaja

2. Pimpinan majelis dhuafa yang tidak mendaptkan upah

Dengan tidak dibayarnya pimpinan majelis dhuafa tentu menjadi faktor pendukung bagi pembentukkan karakter remaja. Sebab, para jama'ah maupun santri tidak dibebani biaya dalam menuntut ilmu dan mengikuti segala kegiatan. Pimpinan majelis dhuafa dengan penuh keikhlasan memberikan ilmu secara sukarela kepada para jamaah dan juga santri.

3. Latar belakang jama'ah yang kurang paham agama

Banyak dari jamaah yang kurang paham agama. Hal ini memudahkan pimpinan majelis dhuafa dalam membentuk karakter para jamaah. Karena tentunya jamaah maupun santri lebih semangat dalam menuntut ilmu.

Selain faktor pendukung terdapat juga faktor penghambat dalam kegiatan pembentukkan karakter remaja yaitu:

1. Sarana dan prasarana yang kurang memadai

Sarana dan prasarana yang kurang memadai terkadang menjadi penghambat proses pembentukkan karakter remaja. Dikarenakan kondisi tempat yang belum terlalu layak, fasilitas yang belum memadai, dan tidak dipungutnya biaya kepada para santri menjadikan sarana dan prasarana belum memadai.

2. Tidak terdapat donatur tetap

Kekurangan biaya mungkin dirasakan karena sudah pasti biaya menjadi faktor yang cukup mendukung untuk mewujudkan sarana dan prasarana yang baik.

3. Latar belakang jamaah yang bermacam-macam

Jamaah memiliki latar belakang yang bermacam-macam dan mereka tentu memiliki karakter masing-masing sehingga terkadang terasa sulit untuk membentuk karakter mereka.

4. Belum didaftarkan majelis di pemerintah secara resmi

\section{Analisis Peranan Majelis Dzikir dalam pembentukkan karakter Remaja}

Setelah melihat dan meneliti apa yang didapatkan peneliti di lapangan kemudian dipaparkan dengan melalui berbagai metodologi dari wawancara, pengamatan atau observasi dan dokumen. Peneliti berusaha menganalisa hasil penelitiannya dengan cara menggambarkan secara keseluruhan dimana hasil tersebut sebagai berikut:

a. Dilihat dari tujuan berdirinya Majelis Dhuafa yaitu memperbaiki hati, jikalau hatinya bersih maka seluruh amal perbuatannay akan menjadi baik

b. Majelis Dhuafa sebagai pioner atau pelopor di setiap kegiatan yang ada di masyarakat sekitar baik dalam kegiatan sosial ataupun kegiatan lainnya, terlihat dari kegiatan membersihkan makam umum dimana pelaku utamanya adalah majelis dhuafa, juga disetiap ada pengajianpengajian dipelopori oleh majelis dhuafa. Usaha ini mampu memberikan pengaruh terhadap pembentukkan karakter remaja.

c. Majelis dhuafa tidak hanya mengadakan kegiatan dzikir dan shalawatan saja namun mengadakan kegiatan-kegiatan lainnya yang mampu memberikan pengaruh terhadap 
pembentukkan karakter remaja diantaranya: yasinan keliling, pengajian rutinan, lari pagi, bersilaturahim, milad dan pentas seni, takbir keliling, minggu bersih.

d. Diantara terlaksananya kegiatan dalam proses pembentukkan ada faktor yang mendorong kegiatan ini adapun faktor pendukungnya adalah: Iklim yang mendukung proses pembentukkan karakter remaja, keikhlasan pimpinan Majelis Dhuafa yang tidak menerima upah maka para jamaah dan santri tidak terbebani oleh biaya dalam menuntut ilmu. Kemudian latar belakang jamaah maupun santri yang kurang paham agama dapat mempermudah proses pembentukkan karakter remaja karena mereka akan lebih bersemangat dalam menuntut ilmu.

Adapun faktor yang menghambat dalam pembentukkan karakter di Majelis Dhuafa adalah: Sarana dan prasarana yang kurang memadai terkadang menjadi penghambat proses pembentukkan karakter remaja. Dikarenakan kondisi tempat yang belum terlalu layak, fasilitas yang belum memadai, tidak terdapat donatur tetap, latar belakang jamaah yang bermacam-macam terkadang agak sulit dibentuk

\section{E. KESIMPULAN}

Setelah melakukan penelitian secara berkala dengan melalui berbagai metodologi penlitian terhadap Majelis Dhuafa dengan judul Peranan Majelis Dzikir dalam Pembentukkan Karakter Remaja, maka penyusun mendapatkan kesimpulan sebagai berikut:

1. Dilihat dari tujuan berdirinya Majelis Dhuafa yaitu memperbaiki hati (Islahul Qalbi), jikalau hatinya bersih maka seluruh amal perbuatannya akan menjadi baik

2. Majelis Dhuafa sebagai pioner atau pelopor di setiap kegiatan yang ada di masyarakat sekitar baik dalam kegiatan sosial ataupun kegiatan lainnya, terlihat dari kegiatan membersihkan makam umum dimana pelaku utamanya adalah majelis dhuafa, juga disetiap ada pengajian-pengajian dipelopori oleh majelis dhuafa. Usaha ini mampu memberikan pengaruh terhadap pembentukkan karakter remaja.

3. Majelis dhuafa tidak hanya mengadakan kegiatan dzikir dan shalawatan saja namun mengadakan kegiatan-kegiatan lainnya yang mampu memberikan pengaruh terhadap pembentukkan karakter remaja diantaranya: yasinan keliling, pengajian rutinan, lari pagi, bersilaturahim, milad dan pentas seni, takbir keliling, minggu bersih dll.

4. Diantara terlaksananya kegiatan dalam proses pembentukkan ada faktor yang mendorong kegiatan ini adapun faktor pendukungnya adalah: Iklim yang mendukung proses pembentukkan karakter remaja, keikhlasan pimpinan Majelis Dhuafa yang tidak menerima upah maka para jamaah dan santri tidak terbebani oleh biaya dalam menuntut ilmu. Kemudian latar belakang jamaah maupun santri yang kurang paham agama dapat mempermudah proses pembentukkan karakter remaja karena mereka akan lebih bersemangat dalam menuntut ilmu.

Adapun faktor yang menghambat dalam pembentukkan karakter di Majelis Dhuafa adalah: Sarana dan prasarana yang kurang memadai terkadang menjadi penghambat proses pembentukkan karakter remaja. Dikarenakan kondisi tempat yang belum terlalu layak, fasilitas yang belum memadai, tidak terdapat donatur tetap, latar belakang jamaah yang bermacam-macam terkadang agak sulit dibentuk

\section{Saran}

Setelah mendaptkan beberapa data dan mengetahuinya di lapangan, yaitu Majelis Dhuafa yang berkaitan dengan peranan Majelis Dzikir dalam pembentukkan Karakter Remaja selalu ada hambatan dalam pelaksanaan kegiatan tersebut, penulis memberikan saran kepada:

1. Pimpinan 
a. Untuk selalu menjaga keistiqomahan dan keikhlasan dalam menggerakkan remaja baik dalam kegiatan spritual ataupun kegiatan harian

b. Mencari donatur tetap untuk Majelis Dhuafa agar tercukupi sarana prasarana di Majelis Dhuafa

c. Mendaftarkan ijin operasional Majelis Dhuafa ke pemerintah agar diakui di pemerintahan

d. Mencari dewan penasehat yang diakui keilmuannya

2. Jamaah dan Santri

a. Para jamaah mengikuti secara aktif di berbagai kegiatan yang ada di Majelis Dhuafa

b. Membantu menginformasikan dan menyebarluaskan tentang Majelis Dhuafa agar dapat dikenal tingkat kabupaten atau nasional tidak di kecamatan saja

c. Ikut berpartisipasi mencari donatur tetap juga dengan menyebarluaskan di jejaring sosial

d. Lebih semangat lagi dalam mengikuti dzikir di Majelis Dhuafa

\section{DAFTAR PUSTAKA}

Arifin, Muhammad, dkk. 2004. Indonesia Berzikir risalah Anak Bangsa untuk Negeri Tercinta( Depok: Intuisi Press, 2004)

Al-Baqir, Muhammad. 2015. Mengobati Penyakit Hati Membentuk Akhlak Mulia. (Bandung: Mizan) cet 1

Asy-Sybaany, Ridwan. 2000. Membentuk Pribadi Lebih Islami (Suatu Kajian Akhlaq). Jakarta Selatan: PT. Intimedia Ciptanusantara.

Aziz, Amin dan Majid Tirmizi Abdul. 2004. Analisa Zikir dan Do'a. Jakarta Timur: Pinbuk Press.

Danim, Sudarwan.2002. Menjadi Peneliti Kualitatif. Bandung: Pustaka Setia.Hadi, Sutrisno. 2004. Metodolgi Research 2. Yogyakarta: Andi Ofset.

Khalid, bin Syekh Abdurrahman. 2012. Kitab Fiqh Mendidik Anak.Jogjakarta: Diva Press)

Labay, Mawardi El Sulthoni. 1992. zikir dan doa dalam Kesibukkan Departemen Penerangan RI. Ilyas, alwahidi dkk. 2006. Islam Tinjauan Spiritual dan Sosial.Cet. I (Yogyakarta: AK Group)

Ma'luf, Luwais. 1986. Al-munjid fi al-Lughah wa al-'alam (Beirut Daar al-Masyriq) cet. ke-33

Moeloeng J, Lexy. 2007. Metodologi Penelitian Kualitatif. ( Bandung: Penerbit PT Remaja Rosdakarya Offset)

Muhammad ,Teungku Hasby Ash Shiddqy. 2002. Pedoman Dzikir dan Doa ( Semarang: PT. Pustaka Riski Putra Cet ke 1)

Riski, Joko Sukmono. 2008. Psikologi Dzikir ( Jakarta: PT Raja Grafindo Persada)

Rasyid, Hamdan. 1992. Konsep Dzikir Menurut Al-Quran dan Urgensinya Bagi Masyarakat Modern. Jakarta Timur: PT Insan Cemerlang. Tanpa tahun penerbit.

Shihab, Quraish. 2017. Yang Hilang Dari Kita Akhlak. Tangerang Selatan: Penerbit Lentera Hati

Warson Ahmad Munawwir. 1997. Kamus Al-Munawwir. Surabaya: Pustaka progresif)

Zainuddin A. dan Muhammad Jamhari. 1999. Al-Islam 2 ; Muamalah dan Akhlaq. Bandung : Pustaka Setia. 